\title{
A preliminary assay on the mixed culture of red Florida tilapia and freshwater prawn Macrobrachium americanum stocked in outdoor tanks at different tilapia densities
}

\author{
Ángel Rojo Cebreros ${ }^{1}$, Marcelo García-Guerrero ${ }^{2}$, Pablo Apun Molina ${ }^{3}$, \\ Apolinar Santamaría Miranda ${ }^{3^{*}}$ \\ ${ }^{1}$ Centro de Investigación en Alimentación y Desarrollo A.C., Unidad Mazatlán en Acuicultura y Manejo Ambiental, Mazatlán, \\ México \\ ${ }^{2}$ Acuacultura de Crustáceos, CIIDIR-IPN Oaxaca, Santa Cruz Xoxocotlán, México \\ ${ }^{3}$ Departamento de Acuacultura, CIIDIR-IPN Unidad Sinaloa, Guasave, México; \\ *Corresponding Author: asantama@ipn.mx
}

Received 9 February 2013; revised 10 March 2013; accepted 5 April 2013

Copyright (C) 2013 Ángel Rojo Cebreros et al. This is an open access article distributed under the Creative Commons Attribution License, which permits unrestricted use, distribution, and reproduction in any medium, provided the original work is properly cited.

\begin{abstract}
Red jumbo tilapia and $M$. americanum prawns were placed in $1000 \mathrm{~L}$ units in polyculture at three different densities of tilapia $(4 / 5,9 / 5$ and $14 / 5 \mathrm{~m}^{2}$; tilapia/prawn) during 112 days with initial weight of $6.5 \pm 2.8 \mathrm{~g}$ for tilapia and $25.9 \pm$ $8.5 \mathrm{~g}$ for prawn. Prawn $\left(0 / 5 \mathrm{~m}^{2}\right)$ and tilapia $(4 / 0$, $9 / 0$ and $14 / 0 \mathrm{~m}^{2}$ ) controls were included. Tanks were maintained outdoors and under shade. Total weight gain (WG), daily individual weight gain (DWG), specific growth rate (SGR), survival, production of gross mass and food conversion ratios (FCR), ammonia, nitrite and nitrate, and chlorophyll a were measured in all units. Only prawn weight gain was significantly higher in polyculture. For tilapia, the highest survival at the end of the trial was $94 \%$ and the lowest was $75 \%$, while prawns had final survival rates from $43 \%$ to $86 \%$. No statistical differences were observed in weight increase among treatments at $p$ $\leq 0.05$.
\end{abstract}

Keywords: Native Prawn; Tilapia; Polyculture; Density

\section{INTRODUCTION}

The freshwater prawn Macrobrachium americanum from Western America has culture potential [1-3]. However, this issue it is understudied and there are not previous studies on its polyculture. Polyculture is an efficient way to use culture units by adding two species with different requirements $[4,5]$. Since 1962 Ling [6] had promoted the polyculture of Macrobrachium prawns with fish such as tilapia. It is known that the polyculture of tilapia and prawns may increase total production and improve profits because of the high market value of prawns [7-9]. Tilapia may tolerate low water quality, can resist infections and has high market value [10]. This fish is often stocked at low densities fed with no balanced diets, so low final yields are obtained [11]. Male tilapia fingerlings may have a weight of $450 \mathrm{~g}$ after five months, but this size could be larger in polyculture [12]. Tilapia has been cultured successfully with prawns (M. rosenbergii, [13]), crayfish (Cherax quadricarinatus, [13]) and shrimp (Litopenaus vannamei, [14]). So, they could be also good if combined with M. americanum (Bate 1868). If possible, the culture of $M$. americanum with tilapia could be suitable in places in which this prawn is native. Tilapia is a very adaptable fish and has different feeding habits than prawns as they feed in the upper level while prawns take food from the bottom $[9,13]$. Mono cultured tilapia may produce significant deposition of surplus organic matter and lower water quality $[12,15]$ while prawns do not utilize the upper level of the water column, thus favoring plankton instability [16]. In addition, inappropriate tilapia densities have been recognized as a factor that causes a low yield $[13,17]$. Therefore, polyculture in proper densities could be more profitable than mono culture.

This issue has been studied on Tilapia but not with $M$. americanum prawns. The aim of this study is to determine the mutual benefit of $M$. americanum and tilapia 
when cultured together at different tilapia densities.

\section{MATERIALS AND METHODS}

\subsection{General Procedure}

The experiment was performed in C.I.I.D.I.R. I.P.N. Sinaloa laboratory, Mexico. A stock of Red Florida tilapia fry (sexually reverted males) was purchased from Aquatic Depot, S.A. de C.V., Mexico. This strain is called Red Jumbo and its genetic heritage is 50\% Florida red tilapia (O. mossambicus) and 50\% Pink Nile tilapia (O. niloticus). They were placed outdoors in a $1000 \mathrm{~L}$ unit and fed with Purina Nutripec initiation (53\% protein, $15 \%$ fat) pellet until they had an average weight of $6.5 \pm$ $1.8 \mathrm{~g}$. Then, 210 specimens with good swimming behavior were selected. At the same time, M. americanum prawns were captured in the Sinaloa River (W107 $30^{\prime}$, $\left.\mathrm{N} 25^{\circ} 00^{\prime}\right)$. They had an average weight of $25.9 \pm 8.5 \mathrm{~g}$. and were acclimated in $1000 \mathrm{~L}$ outdoor tanks during a month before the trial. During this time, they were fed with fresh squid meat and shrimp commercial pellet $(\mathrm{Ca}-$ maronina, Purina, Cd. Obregon, Mexico). Three days before the beginning of the trial, three different densities of tilapia were stocked into the experimental units with and without prawns. Units consisted of 21 round plastic tanks (1.5 m diameter) filled with $1000 \mathrm{~L}$ of fresh water filtered through a sand filter and a $5-\mu$ mesh. Unitss were maintained outdoors, permanently aerated, in static waters, under a shade net and at ambient temperature which during the time of this assay had a daily fluctuation from $22^{\circ} \mathrm{C}$ to $37^{\circ} \mathrm{C}$. In order to register prawn molting, units were checked 3 times per day looking for molts or carcasses which were counted. Experimental design lasted 90 days and consisted of three different tilapia densities each with three replicas, with and without prawns. Selected combinations of tilapia and prawn utilized as treatments were as following:

Treatment 1 , $\left(\mathrm{TP}_{1}\right) 4$ Tilapia/5 prawn per $\mathrm{m}^{2}$. Treatment 2, $\left(\mathrm{TP}_{2}\right) 9$ Tilapia/5 prawn per $\mathrm{m}^{2}$; Treatment 3 , $\left(\mathrm{TP}_{3}\right) 14$ Tilapia/5 prawn per $\mathrm{m}^{2}$; Treatment $4,\left(\mathrm{~T}_{1}\right) 4$ Tilapia/0 prawn per $\mathrm{m}^{2}$; Treatment $5,\left(\mathrm{~T}_{2}\right) 9$ Tilapia/no prawn; Treatment $6,\left(\mathrm{~T}_{3}\right)$ 14/0 prawn per $\mathrm{m}^{2}$; Treatment 7 , (P) 0 Tilapia $/ 5$ prawn per $\mathrm{m}^{2}$.

A $75 \%$ water exchange was done every week with freshwater previously filtered through a sand filter and a $5 \mu$ mesh. Water quality was not strictly controlled but the following parameters were monitored: Dissolved Oxygen (DO) was measured every day at 8:00 $\mathrm{h}$ and at 1600 hours (YSI 150 oxymeter; Yellow springs, Ohio). DO was also measured once a week at 0600 hours as suggested by [18]. Chlorophyll $a$, ammonia, nitrite and nitrate were quantified every week from samples taken at 1200 hours following the techniques of [19] Tilapia was fed with five percent of their average weight with Purina
Nutripec (30\% protein, $6 \%$; lipid) during the first 10 weeks and then food was switched to $25 \%$ protein, $5 \%$ fat Purina Nutripec pellet. Every two weeks all organisms were weighed and measured in its total length and survival of both species was registered. For prawns total length was considered as the distance from the most forward point of the rostrum to the farthest tip of the telson. For tilapia, from the most forward point of the head (mouth closed), to the farthest tip of the tail. Food amount was adjusted at this time depending on the weight. Tilapia food was divided in three equal rations, all given by hand (0700, 1200 and 1800 hours). Since the pellet floats and the fish consumed the food quickly, this food was not available for prawns. Prawns were fed with comercial shrimp pellet (Purina, Mexico, 32\% protein) which was given in a single ration at 1800 hours. This food quickly sinks and Tilapia received food at the same time, so virtually all this food went to the bottom. After 90 days the experiment came to the end. At this time, total weight and total length were recorded for all specimens of all treatments.

\subsection{Measurements}

The following parameters were also calculated as suggested by [12]:

Total weight gain $(\mathrm{g})=$ Total final weight - Total initial weight;

Growth rate $(\mathrm{g})=($ Total final weight - Initial total weight)/Total time in days;

Weight gain per day $[(\mathrm{g}) \times($ day -1$)]=($ average final weight - average initial weight)/days;

Feed conversion ratio $(\mathrm{FCR})=$ food intake $(\mathrm{g}) /$ weight gain $(\mathrm{g})$;

Survival $(\%)=($ total individuals at the end of the trial $\times 100) /$ total individuals at the beginning of the trial;

Specific growth rate or body weight gain per day $(\mathrm{SGR})=[($ Ln final weight $)-(\mathrm{Ln}$ initial weight $) \times 100] /$ Total time in days.

\subsection{Statistical Analysis}

One way ANOVA was performed on mean values, to find possible differences between sizes (total weight) of tilapia or prawns treatments followed by $\mathrm{F}$ test [20]. The $\mathrm{k}$ value, or Fulton condition index which is based on the proper relationship between length and weight [21] was calculated for tilapia. As for water quality variables, also one way Anovas were performed comparing the medias for every day of every variable.

\section{RESULTS}

\subsection{Growth}

The initial, final, total weight gain, daily weight gain (DWG) and specific growth rate (SGR) for tilapia are 
presented in Table 1 while the same parameters for prawns are presented in Table 2. For tilapia, no statistical differences on weight increase were observed among different treatments at all (Table 1; $\mathrm{p} \leq 0.05$ ). Prawns weight increase was not statistically different either (Table $2 ; \mathrm{p} \leq 0.05$ ). However, they were statistically different in total gained weight (Table 2; $\mathrm{p} \leq 0.05$ ).

\subsection{Survival}

For tilapia, the higher survival at the end of the trial was $94 \%$ for $\mathrm{T}_{1}$ (mean $=6.5$ ) and the lowest was $75 \%$ for $\mathrm{TP}_{3}$ (mean $\left.=15.7\right)$ with significant differences on both $(\mathrm{P}$ $\leq 0.05$ ). Prawns had a final survival of $43 \%$ for $\mathrm{P}$ (mean $=3), 48 \%$ for $\mathrm{TP}_{1}($ mean $=3.3), 57 \%$ for $\mathrm{TP}_{2}($ mean $=3.9)$ and $86 \%$ for $\mathrm{TP}_{3}$ (mean $\left.=6.0\right)$. $\mathrm{TP}_{3}$ and all others combinations together were statistically different $(p \leq 0.05)$.

\subsection{Prawn Molt}

After 90 days, the molt frequencies of control (P) were $6.0 \pm 1.7$. TP3 had the lowest molt frequency $(2.3 \pm 0.6)$ with statistical differences as shown in Figure 1. Data lost because of prawn molt counting were not observed since units were constantly monitored and molts were quickly withdrawn, avoiding tilapia or prawns to eat them.

\subsection{Feed Conversion}

Feed conversion ratio (FCR) for the treatments and control for tilapia and prawns are presented in Table 3. No statistical differences were observed $(\mathrm{p} \leq 0.05)$.

\subsection{Biomass Production}

All treatments and controls seem to have biomass values in relation with stocking density. Tilapia bio mass in all treatments had the average values as presented in Figure 2 and prawns in Figure 3.

Table 1. Selected combinations of tilapia and prawn utilized as treatments during a 90-day trial stocked in 1000 liter tanks at different Tilapia (Oreochromis sp.) densities.

\begin{tabular}{cc}
\hline \multicolumn{3}{c}{ Tilapia/prawn density } \\
\hline $\mathrm{TP}_{1}$ & $4 / 5 \mathrm{~m}^{2}$ \\
$\mathrm{TP}_{2}$ & $9 / 5 \mathrm{~m}^{2}$ \\
$\mathrm{TP}_{3}$ & $14 / 5 \mathrm{~m}^{2}$ \\
$\mathrm{~T}_{1}$ & $4 / 0 \mathrm{~m}^{2}$ \\
$\mathrm{~T}_{2}$ & $9 / 0 \mathrm{~m}^{2}$ \\
$\mathrm{~T}_{3}$ & $14 / 0 \mathrm{~m}^{2}$ \\
$\mathrm{P}$ & $0 / 5 \mathrm{~m}^{2}$ \\
\hline
\end{tabular}

\subsection{Biological Indexes}

The $\mathrm{k}$ value between treatments was not statistically different ( $\mathrm{p} \leq 0.05)$ and all had values close to 1 , which is an indicator of fitness (Ricker, 1975). The IHS and IHP did not have statistical differences either at all ( $\mathrm{p} \leq 0.05$; Table 4). Tilapia body composition (Table 5) was mostly carcass (skin + bones + head), secondly body muscle and guts as observed in Table 6 (no statistical differences at $\mathrm{p}$ $\leq 0.05)$.

\subsection{Water Quality Variables}

Daily temperature variations had an average of $29.9^{\circ} \mathrm{C}$ $\pm 1.2^{\circ} \mathrm{C}$ without statistically significant differences $(\mathrm{p} \leq$ 0.05 ). Recorded values were from $28.6^{\circ} \mathrm{C} \pm 1.9^{\circ} \mathrm{C}$ to $31.3^{\circ} \mathrm{C} \pm 1.0^{\circ} \mathrm{C}$ along the trial.

\subsection{Dissolved Oxygen}

The highest values were registered in the control $(\mathrm{P})$ with an interval from $5.7 \pm 0.5$ to $5.8 \pm 0.6 \mathrm{mg} \mathrm{O}_{2} / 1$. The lowest values were observed in $\mathrm{TP}_{3}$ and those were from $4.8 \pm 0.5$ to $5.0 \pm 0.9 \mathrm{mg} \mathrm{O}_{2} / 1$. Significant differences were only obtained between this last treatment and all others at $(\mathrm{p} \leq 0.05)$.

\subsection{Chlorophyll a}

The highest concentrations of chlorophyll $a$ were observed in treatments with more biomass $\left(\mathrm{TP}_{3} ; 16.1\right.$ $\left.\pm 9.3 \mu \cdot \mathrm{gl}^{-1}\right)$ and the lowest in the control (P; $14.6 \pm$ $\left.7.2 \mu \cdot \mathrm{gl}^{-1}\right)$. However, no significant differences were observed $(\mathrm{p} \leq 0.05)$.

\subsection{Nitrogen (N)}

The lowest concentration of ammonia was in the control treatment $(\mathrm{P})$ with a mean of $0.0005 \pm 0.0001 \mathrm{mg} / \mathrm{l}$, while the highest concentration was $0.0279 \pm 0.010 \mathrm{mg} / \mathrm{l}$ $\left(\mathrm{T}_{3}\right)$. Significant differences were observed between $\mathrm{TP}_{1}$ and $\mathrm{T}_{1}$ compared with all others $(\mathrm{p} \leq 0.05)$. The highest concentration of nitrite in this study occurred in the $\mathrm{TP}_{2}$ treatment $(0.30 \pm 0.01 \mathrm{mg} / \mathrm{l})$ while the treatment $\mathrm{P}$ had the lowest $(0.05 \pm 0.07 \mathrm{mg} / \mathrm{l})$. Significant differences were observed between TP1, $\mathrm{T}_{1}$ and $\mathrm{T}_{3}$ in comparison with all others $(\mathrm{p} \leq 0.05)$. For the nitrates, the $\mathrm{P}$ treatment had the lower amount with average of $0.001 \pm 0.002 \mathrm{mg} / \mathrm{l}$ while the highest was in $\mathrm{TP}_{2}(0.32 \mathrm{mg} / \mathrm{l})$. Significant differences were the same as in nitrites $(p \leq 0.05)$. So, a positive correlation $(\mathrm{R}=1.0 ; \mathrm{p} \leq 0.05)$ between nitrate and nitrite concentrations was found.

Water never had critical limits of nitrites, nitrates or $\mathrm{O}_{2}$ in agreement with Dos Santos and Valenti (2002).

\section{DISCUSSION}

None of the densities of tilapias utilized in present 
Table 2. Initial, final and total gained weight and specific growth rate in grams of red Tilapia Oreochromis sp. (media \pm std) during a 90 day trial and stocked in 1000 liter tanks at different Tilapia (Oreochromis sp.) densities.

\begin{tabular}{ccccccc}
\hline & \multicolumn{3}{c}{ Tilapia/Prawn } & & \\
\hline & $\mathrm{TP}_{1}$ & $\mathrm{TP}_{2}$ & $\mathrm{TP}_{3}$ & $\mathrm{~T}_{1}$ & $\mathrm{~T}_{2}$ & $\mathrm{~T}_{3}$ \\
\hline Initial weight & $6.6 \pm 2.7$ & $6.8 \pm 1.8$ & $6.1 \pm 2.3$ & $6.4 \pm 1.7$ & $6.7 \pm 2.0$ & $6.3 \pm 1.1$ \\
Final weight & $122.5 \pm 40.1$ & $128.5 \pm 37.6$ & $132.2 \pm 45.6$ & $111.6 \pm 37.9$ & $119.4 \pm 40.1$ & $117.7 \pm 48.3$ \\
Total gained weight & $116.5 \pm 10.8$ & $122.5 \pm 14.1$ & $126.2 \pm 21.6$ & $105.6 \pm 9.4$ & $113.4 \pm 17.2$ & $111.4 \pm 16.9$ \\
DWG g day $^{-1}$ & $1.0 \pm 0.1$ & $1.1 \pm 0.1$ & $1.1 \pm 0.1$ & $0.9 \pm 0.1$ & $1.0 \pm 0.2$ & $1.0 \pm 0.2$ \\
SGR \% .day $^{-1}$ & $2.5 \pm 0.1$ & $2.5 \pm 0.1$ & $2.6 \pm 0.1$ & $2.4 \pm 0.1$ & $2.4 \pm 0.1$ & $2.5 \pm 0.1$ \\
\hline
\end{tabular}

After ANOVA, treatments were not statistically different at $\mathrm{p} \leq 0.05$.

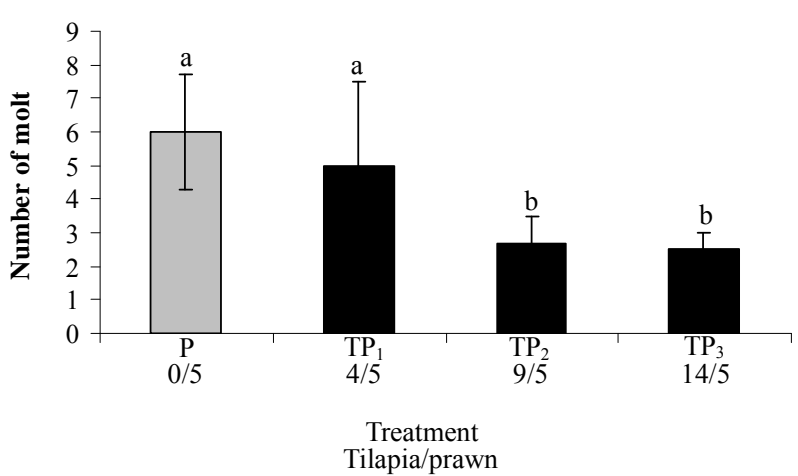

Figure 1. Molt frequency of the prawn $M$. americanum during a 90-day trial and stocked in 1000 liter tanks at different Tilapia (Oreochromis sp.) densities. Bars with different letters are statistically different at $\mathrm{p} \leq 0.05$.

work can guarantee larger fishes since no significant differences on growth increase were obtained, even though fish condition was not affected by density or polyculture, in a trend previously observed [7,8]. Perhaps because the experimental culture conditions, DWG and SGR values of tilapia in this study seems to be lower (1.0 from 2.0 $\mathrm{g} \cdot \mathrm{d}^{-1}$ ) in comparison to other findings (e.g. [22,23]; 2.9 and $2.3 \mathrm{~g} \cdot \mathrm{d}^{-1}$, respectively). However, those works were made in ponds with peryphyton systems, at lower density ( $4 / \mathrm{m}^{2}$ or less) and with $M$. rosenbergii. Though, present proportions of tilapia muscle, guts and carcasses are comparable with that works or even with some works with marine shrimp [14] what suggests the independence of this proportions from culture density.

In the case of prawns, only the mean biomass for total weight gained (Figure 3) was significantly greater in TP3 with the highest tilapia growth and highest prawn survival. This supports that this polyculture could be suitable even at the highest density here utilized. Considering total gained weight values of present work (Table 2), it seems that high tilapia density could benefit prawn more than fish. Also, the best FCR for tilapia was at low density, being similar to Nile tilapia (O. niloticus) cultured with Litopenaeus vannamei [14]. However, for prawns this was at the highest density which suggests the
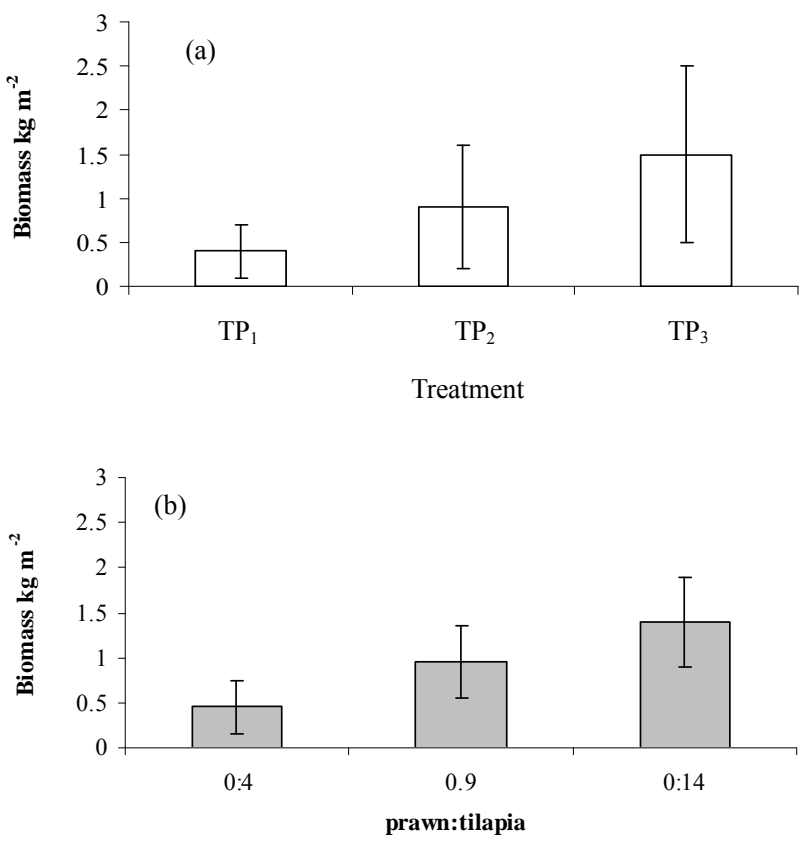

Figure 2. (a) Biomass obtained of red tilapia (Oreochromis sp.) during a 90-day trial and stocked in 1000 liter tanks at different densities in Polyculture with the prawn M. americanum; (b) Biomass obtained of red tilapia (Oreochromis sp.) at different densities with no prawns.

benefit of tilapia presence for prawns.

In present study, no statistical differences were observed on prawn SGR values as previously obtained by $[7,24,25]$. IHP and HIS indexes (utilized to predict tilapia nutritional status [26], in this study had a lower average value in polyculture $(3.0 \pm 0.7)$ compared with monoculture $(3.3 \pm 1.0)$ but with no statistical differences, as also observed by [27].

It is suggested that prawn and tilapia growth was not affected by co-existence in present work. There are no previous documented studies on $M$. americanum polyculture, yet [9] found in monoculture with this prawn, similar sizes to that of present work and suggested that its growth curve is comparable to $M$. rosenbergii. Indeed, there is plenty of previous work with that species sustaining its culture with tilapia [24,28,29]. 
Table 3. Initial, final and gained weight in grams PGD (per day, $\mathrm{g} \cdot \mathrm{d}^{-1}$ ) and TCE (specific growth rate, $\% \cdot \mathrm{d}^{-1}$ ) of the prawn Macrobrachium americanum (media \pm std) during a 90-day trial and stocked in 1000 liter tanks at different Tilapia (Oreochromis sp.) densities.

\begin{tabular}{ccccc}
\hline & $\mathrm{P}$ & $\mathrm{TP}_{1}$ & $\mathrm{TP}_{2}$ & $\mathrm{TP}_{3}$ \\
\hline Initial weight & $25.3 \pm 8.2 \mathrm{a}$ & $26.1 \pm 7.5 \mathrm{a}$ & $25.7 \pm 8.4 \mathrm{a}$ & $26.5 \pm 8.0 \mathrm{a}$ \\
Final weight & $41.2 \pm 1.3 \mathrm{a}$ & $45.8 \pm 1.4 \mathrm{a}$ & $45.4 \pm 2.7 \mathrm{a}$ & $46.0 \pm 1.4 \mathrm{a}$ \\
Total gained weight & $16.2 \pm 1.3 \mathrm{a}$ & $20.8 \pm 1.4 \mathrm{ab}$ & $20.3 \pm 2.6 \mathrm{ab}$ & $20.9 \pm 1.4 \mathrm{~b}$ \\
DWG g·d-1 & $0.1 \pm 0.01 \mathrm{a}$ & $0.2 \pm 0.01 \mathrm{~b}$ & $0.2 \pm 0.02 \mathrm{ab}$ & $0.2 \pm 0.01 \mathrm{~b}$ \\
SGR \%·d-1 & $0.4 \pm 0.03 \mathrm{a}$ & $0.5 \pm 0.03 \mathrm{a}$ & $0.5 \pm 0.05 \mathrm{a}$ & $0.5 \pm 0.03 \mathrm{a}$ \\
\hline
\end{tabular}

From ANOVA, different letters means statistical differences at $(\mathrm{p} \leq 0.05)$.

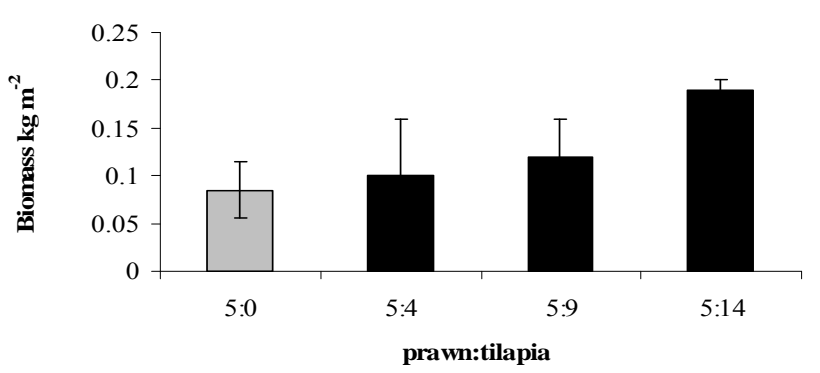

Figure 3. Total biomass obtained of the prawn M. americanum in a 90-day trail and stocked in 1000 liter tanks at different Tilapia densities.

In present work, survival was lower for tilapia at high densities, even though units with crowded tilapia produced more total tilapia biomass and higher prawn survival. However, even the lower survival reported here for tilapia is common in this kind of experiments $[13,22$, $23,28,30]$. In agreement with those authors, prawns have no negative effect on tilapia survival and total tilapia biomass obtained with prawns at present work is as comparable to most reports with similar experimental designs $[15,28,31]$ and higher than some prawn monoculture works $[15,32]$. Prawns present survival also seems to be as expected in polyculture, even though previous works were done with $M$. rosenbergii. In those works, prawn survival (polyculture or monoculture) use to be from $39 \%$ to $57 \%[9,12,15]$. The cause of highest prawn survival in this work at high tilapia density was not directly studied but possibly, the organic matter accumulated in the bottom or produced because of the tilapia activity, may help to satisfy prawn needs in addition to pellet. Also, Tilapia may help to counteract cannibalism, one of the main causes of mortality in prawn culture [33]. It has been stated before that Tilapia might improve water quality in benefit of prawns $[8,16,28]$. Larger prawns were produced in polyculture, a fact that supports this previously stated fact $[8,16,28,34]$ Most previous research agree on this topic even considering that some studies had report low prawn survival or low growth when it is cultured with tilapia [7,30]. Previous authors suggest that interespecific competition may exist be-
Table 4. Feed conversion ratio (FCR) of Oreochromis sp. (above) and prawn $M$. americanum (below) during a 90-day trial and stocked in 1000 liter tanks at different Tilapia (Oreochromis sp.) densities.

\begin{tabular}{cccccc}
\hline $\mathrm{TP}_{1}$ & $\mathrm{TP}_{2}$ & $\mathrm{TP}_{3}$ & $\mathrm{~T}_{1}$ & $\mathrm{~T}_{2}$ & $\mathrm{~T}_{3}$ \\
\hline $1.6 \pm 0.2$ & $1.5 \pm 0.1$ & $1.4 \pm 0.2$ & $1.5 \pm 0.1$ & $1.5 \pm 0.1$ & $1.3 \pm 0.1$ \\
$\mathrm{P}$ & $\mathrm{TP}_{1}$ & $\mathrm{TP}_{2}$ & $\mathrm{TP}_{3}$ & & \\
$1.5 \pm 0.1$ & $1.6 \pm 0.7$ & $1.7 \pm 0.2$ & $1.7 \pm 0.1$ & & \\
\hline
\end{tabular}

No significant differences among treatments and controls were observed (p $\leq 0.05$ ).

tween large prawns and tilapias, but this behavior was not observed in present work, even considering that $M$. americanun is often aggressive [2,3,35].

Biological indexes such as the $\mathrm{K}$ condition factor could be stress indicators [36] but in present work, $\mathrm{K}$ value was always acceptable for tilapia in agreement with [37], suggesting that density may have a negative effect on survival but not in fitness. In fact, prawn FCR in present work was higher in polyculture. In regard to IHP and IHS values, it is known that the higher the value, the better the nutritional condition [26]. IHP results of this study were not statistically different; suggesting that polyculture at the higher density may not cause fitness problems, as previously observed by [27].

On the other hand, water quality parameters such as temperature, dissolved oxygen, chlorophyll a, $\mathrm{NO}_{2}$ and $\mathrm{NH}_{3}$ were always inside safe levels in agreement with $[18,29,30,38]$, so mortalities or lower growth might not be related to water quality. Also, the highest concentrations of chlorophyll $a$ in this study were registered in the treatments with more Tilapia $\left(\mathrm{T}_{2}\right.$ and $\left.\mathrm{T}_{3}\right)$. This fish produces high amounts of $\mathrm{N}$ wastes [39] but even the higher values of $\mathrm{N}$ wastes registered here were within the interval recommended by [40], suggesting that even the highest biomass utilized here was suitable in terms of water quality.

\section{CONCLUSSION}

Present results indicate that tilapia and M. americanum polyculture in tanks actually improves prawn production 
Table 5. Biological indexes $(\mathrm{FC}=$ condition factor $\mathrm{K}$, IHS = hepatosomatic Index, IHP = hepatopancreatic Index) of red tilapia Oreochromis sp. during a 90-day trial and stocked in 1000 liter tanks at different Tilapia (Oreochromis sp.) densities.

\begin{tabular}{cccccccc}
\hline & $\mathrm{TP}_{1}$ & $\mathrm{TP}_{2}$ & $\mathrm{TP}_{3}$ & $\mathrm{~T}_{1}$ & $\mathrm{~T}_{2}$ & $\mathrm{~T}_{3}$ & $\mathrm{P}$ \\
\hline FC & $1.0 \pm 0.2$ & $1.1 \pm 0.2$ & $1.1 \pm 0.1$ & $1.0 \pm 0.2$ & $1.0 \pm 0.1$ & $1.0 \pm 0.1$ & - \\
IHS & $1.8 \pm 0.2$ & $2.1 \pm 0.6$ & $2.8 \pm 0.6$ & $2.4 \pm 1.7$ & $2.0 \pm 0.9$ & $2.3 \pm 0.7$ & - \\
IHP & $4.1 \pm 1.9$ & $3.9 \pm 0.8$ & $3.0 \pm 0.7$ & - & - & - & $3.3 \pm 1.0$ \\
\hline
\end{tabular}

By Anova, no significant differences between treatments and controls were obtained $(\mathrm{p} \leq 0.05)$.

Table 6. Body composition in percentages of the red tilapia Oreochromis sp. ( \pm std dev) during a 90 -day trial and stocked in 1000 liter tanks at different Tilapia (Oreochromis sp.) densities. S.C. $=$ Stomach content.

\begin{tabular}{ccccccc}
\hline$\%$ & $\mathrm{TP}_{1}$ & $\mathrm{TP}_{2}$ & $\mathrm{TP}_{3}$ & $\mathrm{~T}_{1}$ & $\mathrm{~T}_{2}$ & $\mathrm{~T}_{3}$ \\
\hline Muscle & $31.0 \pm 2.0$ & $30.9 \pm 1.9$ & $31.2 \pm 1.1$ & $30.9 \pm 1.4$ & $31.1 \pm 0.9$ & $31.5 \pm 1.2$ \\
Carcass & $54.9 \pm 3.1$ & $55.5 \pm 1.6$ & $55.3 \pm 1.8$ & $55.1 \pm 2.4$ & $54.1 \pm 2.1$ & $54.1 \pm 1.9$ \\
Guts & $9.6 \pm 2.0$ & $11.5 \pm 1.5$ & $10.8 \pm 1.2$ & $11.2 \pm 0.8$ & $12.1 \pm 1.1$ & $13.2 \pm 1.2$ \\
S.C. & $4.5 \pm 2.5$ & $2.1 \pm 1.4$ & $2.7 \pm 1.4$ & $2.8 \pm 1.0$ & $2.3 \pm 1.8$ & $1.2 \pm 0.8$ \\
\hline
\end{tabular}

No significant differences $(\mathrm{p} \leq 0.05)$ were obtained.

and increases total animal biomass. Since no one of these treatments is statistically better than the others, the highest density here utilized could be suggested for further research, which could be performed in small experimental ponds, perhaps with farm raised prawns, prior to intent this kind of culture at a further production level.

\section{ACKNOWLEDGEMENTS}

Authors wish to thank Biol. Amos Valdez and Biol. Oscar Low for their assistance during maintenance and animal handling. This project received funds from CECyT Sinaloa (SIN2007 C01 6895) and SIP IPN (20080116 and 20090094). M. García-Guerrero also wishes to thank IPN EDI and COFAA scholarship programs.

\section{REFERENCES}

[1] García-Guerrero, M. and Apún Molina, J. (2008) Density and shelter influence the adaptation to wild juvenile cauque prawns Macrobrachium americanum to culture conditions. North American Journal of Aquaculture, 70, 343346. doi:10.1577/A07-041.1

[2] García-Guerrero, M. (2009) Proximate biochemical variations in eggs of the prawn Macrobrachium americanum (Bate, 1869) during its embryonic development. Aquaculture Reasearch, 40, 575-581. doi:10.1111/j.1365-2109.2008.02133.x

[3] García-Guerrero, M., Orduña-Rojas, J. and Cortes, E. (2011) Oxygen consumption of the prawn Macrobrachium americanum (Bate 1868) over the temperature range of its native environment and in relation to its weight. North American Journal of Aquaculture, 73, 320-326. doi:10.1080/19425120.2011.601982

[4] Swingle, H. (1966) Biological means of increasing productivity in ponds. Proceedings of the FAO World Symposium on Pondfish Culture and Fish Reproduction, 44, 243-257.
[5] Yashouv, A. and Halevy, A. (1972) Experimental studies of polyculture in 1971. Israeli Journal of Aquaculture, 24, 40-48.

[6] Ling, S. (1962) Studies on the rearing of larvae and juveniles and culturing adults of Macrobrachiurn rosenbergii (de Man). Current Affairs Bulletin, No. 35, Indo-Pacific Fisheries Commision, Bangkok, Thailand.

[7] Uddin, S., Mohd, E., Wahab, A. and Verdegem, M. (2006) The potential of mixed culture of genetically improved farmed tilapia (Oreochromis niloticus) and freshwater giant prawn (Macrobrachium rosenbergii) in periphyton-based systems. Aquaculture Reasearch, 37, 241-247. doi:10.1111/j.1365-2109.2005.01424.x

[8] Dos Santos, M. and Valenti, W. (2002) Production of Nile tilapia Oreochromis niloticus and freshwater prawn Macrobrachium rosenbergii stocked at different densities in polyculture systems in Brazil. Journal of the World Aquaculture Society, 33, 369-373. doi:10.1111/j.1749-7345.2002.tb00513.x

[9] Asaduzzaman, A., Wahab, M., Verdegem, M. and Mondal-Azim, M. (2009) Effects of stocking density of freshwater prawn Macrobrachium rosenbergii and addition of different levels of tilapia Oreochromis niloticus on production in $\mathrm{C} / \mathrm{N}$ controlled periphyton based system. Aquaculture, 286, 72-79. doi:10.1016/j.aquaculture.2008.09.006

[10] Apun, J., Santamaría, A., Luna, A., Martínez, S. and Contreras, M. (2009) Effect of potential probiotic bacteria on growth and survival of tilapia Oreochromis niloticus cultured in the laboratory under high density and suboptimum temperature. Aquaculture Reasearch, 40, 887-894. doi:10.1111/j.1365-2109.2009.02172.x

[11] Ponce, D., Hernández, O. and Gasca, E. (2006) Simulating the economic viability of Nile tilapia and Australian redclaw crayfish polyculture in Yucatan, Mexico. Aquaculture, 261, 151-159.

[12] Uddin, S., Farzana, A., Fatema, A., Azim, A., Wahab, M. and Verdegem, J. (2007) Technical evaluation of tilapia 
(Oreochromis niloticus) mono culture and tilapia-prawn (Macrobrachium rosenbergii) polyculture in earthen ponds with or without substrates for periphyton development. Aquaculture, 269, 232-240.

doi:10.1016/j.aquaculture.2007.05.038

[13] Rouse, D. and Mulla, A. (1987) Effects of stocking size and density of tilapia on Macrobrachiurn rosenbergii in polyculture. Journal of the World Aquaculture Society, 18, 57-60. doi:10.1111/j.1749-7345.1987.tb00418.x

[14] Muangkeow, B., Ikejima, S., Powtongsook, S. and Yi, Y. (2007) Effects of white shrimp Litopenaeus vannamei (Boone), and Nile tilapia, Oreochromis niloticus stocking density on growth, nutrient conversion rate and economic return in integrated recirculation system. Aquaculture, 269, 363-376. doi:10.1016/j.aquaculture.2007.04.002

[15] Tidwell, J., Coyle, S., Van Arnum, A., Weibel, C. and Harkins, S. (2000) Growth, survival and body composition of cage culture Nile tilapia Oreochromis niloticus fed pelleted and unpelleted distillers grains with soluble in polyculture with freshwater prawn Macrobrachium rosenbergii. Journal of the World Aquaculture Society, 31, 627631. doi:10.1111/j.1749-7345.2000.tb00912.x

[16] Cohen, D., Ra'anana, Z. and Barnesa, A. (1983) Prodution of the freshwater prawn Macrobrachium rosenbergii in Israel, I. Integration into fish polyculture systems. Aqaculture, 31, 67-76.

[17] Gall, G. and Bakar, Y. (1999) Stocking density and tank size in the design of breed improvement programs for body size of tilapia. Aquaculture, 173, 197-205. doi:10.1016/S0044-8486(98)00487-6

[18] D'Abramo, L. and Brunson, M. (1996) Production of freshwater prawns in ponds. Southern Regional Aquaculture Center Publication, SRAC 484.

[19] Strickland, J. and Parsons, R. (1972) A practical handbook of seawater analysis. 2nd Edition, Fisheries Research Board of Canada.

[20] Zar, J. (1999) Biostatistical analysis. Prentice-Hall, Englewood Cliffs.

[21] Ricker, W. (1975) Computation and interpretation of biological statistics of fish populations. Fisheries Research Board Canadian Bulletin, 191, 1-382

[22] Garduño, M., Granados, M., Olvera, A. and Muñoz, G. (2003) Comparison of growth, fillet yield and proximate composition between Stirling Nile tilapia (wild type) (Oreochromis niloticus, Linneus) and red hybrid tilapia (Florida red tilapia Stirling red O. niloticus) males. Aquaculture Reasearch, 34, 1023-1028. doi:10.1046/j.1365-2109.2003.00904.x

[23] Garduño, M., Herrera, J., Angulo, J., Muñoz, G. and Cruz, J. (2007) Nutrient composition and sensory evaluation of fillets from wild-type Nile tilapia (Oreochromis niloticus, Linneus) and red hybrid (Florida red tilapia $\mathrm{x}$ red $O$. niloticus). Aquaculture Reasearch, 38, 1074-1081. doi:10.1111/j.1365-2109.2007.01773.x

[24] Hossain, M. and Paul, K. (2007) Low-cost diet for monoculture of giant freshwater prawn (Macrobrachium rosenbergii de Man) in Bangladesh. Aquaculture Reasearch, 38, 232-238. doi:10.1111/j.1365-2109.2007.01652.x
[25] Danaher, J., Tidwell, J., Coyle, D. and Dasgupta, S. (2007) Effects of two densities of caged monosex nile tilapia Oreochromis niloticus on water quality, phytoplankton populations, and production when polyculture with Macrobrachium rosenbergii in temperate ponds. Journal of the World Aquaculture Society, 38, 367-382. doi:10.1111/j.1749-7345.2007.00109.x

[26] Collins, A. and Anderson, T. (1995) The regulation of endogenous energy stores during starvation and re feeding in the somatic tissues of the golden perch. Journal of Fish Biology, 47, 1004-1015. doi:10.1111/j.1095-8649.1995.tb06024.x

[27] Bahurmiz, O. and Ng, K. (2007) Effects of dietary palm oil source on growth, tissue fatty acid composition and nutrient digestibility of red hybrid tilapia, Oreochromis sp. raised from stocking to marketable size. Aquaculture, 262, 382-392. doi:10.1016/j.aquaculture.2006.11.023

[28] García-Perez Alston, D. and Cortes, R. (2000) Growth, survival, yield, and size distributions of freshwater prawn Macrobrachium rosenbergii and tilapia, Oreochromis niloticus in polyculture and monoculture systems in Puerto Rico. Journal of the World Aquaculture Society, 31, 446451.

[29] Siddique, A., Howlader, M. and Adam, A. (1989) Culture of Nile tilapia, Oreochromis niloticus (L.) at three stocking densities in outdoor concrete tanks using drainage water. Aquaculture Fisheries and Management, 20, 4957.

[30] Rouse, D. and Kahn, B. (1998) Production of Australian Red Claw Cherax quadricarinatus in polyculture with Nile tilapia Oreochromis niloticus. Journal of the World Aquaculture Society, 29, 340-344. doi:10.1111/j.1749-7345.1998.tb00656.x

[31] Tidwell, J., Coyle, S. and Dasgupta, S. (2004) Effects of stocking different fractions of size graded juvenile prawns on production and population structure during a temperature-limited grow out period. Aquaculture, 231, 123-134. doi:10.1016/S0044-8486(03)00544-1

[32] Daniels, W. and D'Abramo, L. (1994) Pond production characteristics of freshwater prawns Macrobrachium rosenbergii as influenced by the stocking of size-graded populations of juveniles. Aquaculture, 122, 33-45. doi:10.1016/0044-8486(94)90331-X

[33] Nair, K., Bransilav, N., Rosenthal, H. and Nost, J. (1999) Experimental studies on the cannibalistic habit of Macrobrachium rosenbergii de man. The Fourth Indian Fisheries Forum Proceeding, 24, 227-232.

[34] Wang, J., Li, D., Dong, S., Wang, K. and Tian, X. (1998) Experimental studies on polyculture in closed shrimp ponds. I. Intensive polyculture of Chinese shrimp Penaeus chinensis with tilapia hybrids. Aquaculture, 163, 1127. doi:10.1016/S0044-8486(98)00165-3

[35] García-Guerrero, M. and Orduña-Rojas, J. (2010) Growth and survival of Macrobrachium americanum Bate, 1868 juvenile prawns (Crustacea, Decapoda Palaemonidae) stocked in tanks at different sizes. World Aquaculture Magazine, 41, 58-60.

[36] Wedemeyer, G. (1970) The role of stress in disease resistance of fishes and shellfishes. American Fishery Society 
Symposium on the Diseases of Fish and Shellfish, Special publication No. 5 .

[37] Huang, W. and Chiu, T. (1997) Effects of stocking density on survival, growth, size variation, and production of Tilapia fry. Aquaculture Reasearch, 28, 165-173. doi:10.1111/j.1365-2109.1997.tb01029.x

[38] Miao, I. (1992) Growth and survival model of red tail shrimp Penaeus penicillatus (Alock) according to manipulating stocking density. Bulletin of Institutional Zoology Society, 31, 1-8.
[39] Evans, J., Pasnik, D., Brill, G. and Klesius, P. (2006) Unionized ammonia exposure in nile tilapia, Toxicity, stress response, and susceptibility to Streptococcus agalactiae. North American Journal of Aquaculture, 68, 23-33. doi:10.1577/A05-032.1

[40] Boyd, C. and Zimmerman, S. (2000) Grow-out systemswater quality and soil management. In: New, M.B. and Valenti, W.C., Eds., Fresh Water Farming. The Farming of Macrobrachium rosenbergii. Blackwell Science, Oxford, 221-238. 